\title{
Assembling the dodo in early modern natural history
}

\section{NATALIE LAWRENCE*}

\begin{abstract}
This paper explores the assimilation of the flightless dodo into early-modern natural history. The dodo was first described by Dutch sailors landing on Mauritius in 1598, and became extinct in the 1680s or ' $90 \mathrm{~s}$. Despite this brief period of encounter, the bird was a popular subject in natural history works and a range of other genres. The dodo will be used here as a counter-example to the historical narratives of taxonomic crisis and abrupt shifts in natural history caused by exotic creatures coming to Europe. Though this bird had a bizarre form, early-modern naturalists integrated the dodo and other flightless birds through several levels of conceptual categorisation, including the geographical, morphological and symbolic. Naturalists such as Charles L'Écluse produced a set of typical descriptive tropes that helped make up the European dodo. These long-lived images were used for a variety of symbolic purposes, demonstrated by the depiction of the Dutch East India enterprise in Willem Piso's 1658 publication. The case of the dodo shows that, far from there being a dramatic shift away from emblematism in the seventeenth century, the implicit symbolic roles attributed to exotic beasts by naturalists constructing them from scant information and specimens remained integral to natural history.
\end{abstract}

\section{Introduction}

Amongst the natural exotics brought to Europe in the seventeenth century, the dodo was one of the more unusual, yet also one of the least treasured. The first descriptions of the bird to be published were written in 1598 by Dutch sailors stopping at Mauritius en route to the Indies via the Cape of Good Hope. Even beyond its extinction in the late seventeenth century, the dodo was an iconic creature in Europe, closely linked to the trading enterprise of the Dutch East India Company (Vereenigde Oost-Indische Compagnie, hereafter VOC). Few whole or partial dodo specimens were ever brought to Europe, although many were loaded as provisions onto trading ships bound for the Indies. It was not prized as a valuable commodity as were the bird of paradise skins sold by traders in the East Indies; nor was it found in menageries like the parrots shipped over from the New World or Asia. Yet the dodo was a familiar figure in Northern European natural histories, travelogues and paintings throughout the seventeenth century. The image of the composite dodo was valuable even though its disparate physical parts were not widely traded.

Modern authorities on dodos, such as Anthony Cheke and Julian Hume, have carefully scoured this disjointed assemblage of bones and beaks, painted images and printed accounts to determine the 'real' dodo's form. The paleobiologist, Jolyon C. Parish published an exhaustive compendium of much of the available dodo material, both contemporary and secondary discussions on the subject, in 2013. I am indebted to the painstaking work carried out in producing such accounts, but this article will use the material unearthed by these studies in a very different way. My plan is not to recreate the biological reality of the Mauritian dodo, but rather its iconographic life in Europe. ${ }^{1}$ 
This article will explore how the dodo was assimilated into European natural history through the same processes as exotic creatures that were more economically valued in Europe. Emma Spary has explored the way in which the colonial botanist 'as a figure of epistemological expertise' was 'a retrospectively fashioned identity' resulting from the outcome of disputes. She argues that species were 'not born, but made in a process of negotiation' between interested parties. ${ }^{2}$ This article makes the complementary argument that the exotic 'species' described in Europe were as much the result of the knowledge-creating practices of naturalists looking towards the colonies as the physical material transported to Europe.

In the interests of brevity, two publications will form the focus of this article, the Exoticorum libri decem (1605) of the Flemish botanist Charles L'Écluse (Carolus Clusius) and the Historiae naturalis et medicae (1658) of Jacob de Bont (Jacobus Bontius). These two volumes were produced in very different circumstances. L'Écluse worked in Leiden, gathering material through a network of correspondents. He assembled the first natural history of the dodo in the Exoticorum, shortly after the Dutch first landed on Mauritius in 1598, although the Portuguese had probably known of the island earlier. L'Écluse generated a core set of imagery that would be used to characterise the bird throughout the following century. The account in de Bondt's volume, in contrast, was garnered from printed sources, including L'Écluse's, more than sixty years later. There is little difference in terms of informational content between these two works, but their authors deployed natural historical imagery very differently, leading to two divergent textual 'dodos'. The early-modern images of the dodo were very unusual, in that they remained unaffected by new material because of the bird's almost complete absence from Europe. These seventeenth-century dodo images circulated in natural histories, as well as other print forms and art, for centuries after their creation.

I will address two much-debated historical narratives. The first concerns the classification of exotic naturalia brought to Europe in the seventeenth century. Some historians have argued that exotica created a crisis of classification in early-modern natural history. Brian Ogilvie, for example, refers to the 'dizzying pace of discovery' of new species creating 'problems of organisation'. In contrast, Harriet Ritvo's account of taxonomic developments from the Enlightenment demonstrates that difficult to categorise creatures were not a source of anxiety or crisis amongst the energetic proliferation of taxonomies in the eighteenth century. Rather, anomalous and boundary-crossing creatures were a persistent source of fascination well into the nineteenth century. ${ }^{3}$

Other historians have framed the changes that occurred through the early modern period as a more gradual process of replacement, as Anthony Grafton does in his exploration of how classical texts formed a scaffold upon which new natural knowledge was constructed.

Similarly, Florike Egmond describes the European use of extant categories to assimilate new things as a result of the 'blank European ignorance in the face of unknown exotic nature'. She characterises the primary goal of early-modern naturalists as the 'approximation of unknown naturalia...to known ones', with an emphasis on the comparative and descriptive, rather than a 'ubiquitous taxonomy'. Londa Schiebinger even suggests that the 'cultured and gendered frameworks' through which Europeans approached New World both 'set research priorities' and made European travellers 'unable to absorb radically new information'. A complementary perspective to these arguments is Dániel Margócsy's recent account of entrepreneurial early-modern science, in which he shows how taxonomies developed in response to the international trade in cabinet specimens. Larger animals that were difficult to preserve, being much less traded, were not a taxonomic focus for early-modern naturalists. ${ }^{5}$ 
The strange form of flightless birds like the dodo and cassowary certainly did not fit existing concepts of the avian. While these birds were 'without history' from classical authorities, they were not a severe structural challenge to natural historical constructs. ${ }^{6}$ They were conceptualised within a system of categories that were in part traditional and in part newly constructed. But their assimilation was not achieved through the resolution of a fundamental conflict between 'new' and 'old' taxonomies. Early-modern categorisations of the natural world operated on multiple different registers, involving many types of physical and symbolic affinities and distinctions. ${ }^{7}$ These structures were not rigid: their boundaries could be extended or blurred to accommodate seemingly challenging objects. ${ }^{8}$ Thus, the apparently contrary nature of the dodo was defused by its identities as an exotic 'Indian bird' and a flightless 'monster'.

In addition, this article will address the narrative of the shift away from emblematics towards a new 'objective' natural history. William Ashworth has described natural history being 'liberated' from the tradition of emblematic significances. ${ }^{9}$ He credits the arrival of unknown New World creatures and plants as being the driving force behind the 'bottom' dropping 'right out of the emblematic cosmos'. ${ }^{10}$ More recent work suggests a more complex story. Charlotte Sleigh, for example, has demonstrated how the negative theological attributes of a familiar creature, the frog, were a major obstacle that Jan Swammerdam had to overcome in order to demonstrate the frog's empirical value to his unified theory of generation. ${ }^{11}$ Eric Jorink, similarly, describes a shift in the seventeenth-century from a view of insects as emblems of God's nature, to the idea that God could be perceived in them directly. ${ }^{12}$ Though never incorporated into formal books of emblems, the seventeenth-century European 'dodo' was a construction that had emblematic functions, a mobile set-piece that was coopted for a variety of symbolic purposes. In particular, the dodo became a gluttonous creature, imbued with the moral overtones of the consumptive enterprise of the VOC. There are other examples of the symbolic uses of natural things. Karin Leonhard, for example, has described the beautiful conchological imagery used to symbolise the 'interrelations between commerce and riches in the Dutch Republic'. ${ }^{13}$ The dodo was a dark counterpart to the more positive images that Leonhard explores.

\section{Constructing the dodo}

Naturalists created the dodo in the absence of much physical dodo material. The dodo was not valued as a commodity, neither as a luxury item nor as a valuable raw material. This might have been because these birds from uninhabited Mauritius had not been part of an existing system of exchange and trade; they had no preexisting economic value before European arrival. Instead, they served as provisions, salted and packed into barrels on European ships en route to the East Indies. Few carcasses or dodo parts were brought back on trading ships, perhaps because they were rapidly consumed and disposed of, or because all large, fleshy animals were extremely difficult to preserve on long voyages. Such creatures usually had to be dismantled and only the most easily preserved and valuable pieces brought back: in the case of the dodo, the head, beak and legs. ${ }^{14}$ Some specimens did arrive in Europe, possibly even a few live dodos, and these were acquired by both princely and more modest mercantile and scholarly collectors. ${ }^{15}$ However, the pieces that did exist in Europe did not combine to form a whole dodo: they formed only a small piece of the puzzling creature. Rather, the assemblage of 'type' images actively created by naturalists was what constituted the 'dodo' in Europe, far more than physical specimens of the bird. 
Lacking 'traditional ingredients', the histories of exotic animals may have posed 'unique challenges', but writing them also yielded unique opportunities for constructing creatures that fulfilled a variety of authorial agendas. ${ }^{16}$ L'Écluse's Exoticorum libri decem is a virtual cabinet of the exotica to which he had been exposed over many decades of energetic interaction with a network of scholars, collectors, travellers and other groups. ${ }^{17}$ L'Écluse strove to include the most recently arrived exotic naturalia in his publication. He was in competition with other authors and publishers seeking to position themselves in a flourishing market for such publications as purveyors of the most recent natural knowledge. ${ }^{18}$

Though well into old age and with failing health, L'Écluse worked to collect specimens or direct observational accounts of the creatures that he described. He explicitly argued that true knowledge had to be based on observation. ${ }^{19}$ However, L'Écluse could not see all of the creatures that he described alive or even as specimens, nor could he physically show them to his readers. This was certainly the case with the dodo, which L'Écluse never saw. He had to fill the interstices between the limited reach of his experience and the information that he conveyed. As Michael Wintroub has described for Robert Boyle's experimental descriptions, L'Écluse had to make 'unreliable words' the conduit for experience of 'reliable things', both first and second-hand. ${ }^{20}$ To describe the dodo in Europe, where few had seen dodos, L'Écluse had to draw together the available sources of knowledge with which to assemble the animal. ${ }^{21}$ L'Écluse gathered what accounts he could from his network of correspondents, journals and specimen owners, and presented them to the reader. He used the verbal images of his text to create the impression of seeing the assembled elements of the bird itself. ${ }^{22}$

L'Écluse linked the dodo to the particulars of its first discovery, using some of the travelogues published of the first voyages stopping at Mauritius. One of these was the Het Tweede Boeck, journael oft dagh-register Amsterdam (1601). ${ }^{23}$ Additional information in L'Écluse's account also suggests that he had access to other sources such as the original ship journals. ${ }^{24}$ Presenting the bird as an exotic discovered in a particular time and place, and by a particular group of sailors, was an essential part of the 'history of the bird'. This set-piece encounter story served as one of the tropes from which the bird was composed.

In his text, L'Écluse moved seamlessly between the library and cabinet, the docks where exotic material arrived, and the printing press. He brought the reader not only into the sailors' first experiences of Mauritius, but also into his own experience of seeing the sailor's journals:

Meanwhile, while they were abiding on the island, they observed birds of a varied type; among those one very strange, of which [I saw] a rough small figure sketched in the journal containing the whole history of that voyage... set forth in this chapter. ${ }^{25}$

L'Écluse used this 'rough small figure' as a basis for his own woodcut, linking together the sailor's experience of the bird, his transmission of this information and the woodcut in L'Écluse's publication [Figure 1]. Travellers' testimonies were notoriously unreliable, but dealing with the sailor's testimony in this way elevated them from travel tales to verified experience bearing witness to the discovery and form of the bird. ${ }^{26}$ 
L'Écluse's other sources of information were two dodo artifacts that he saw for himself. His colleague at Leiden University, the 'illustrious' Peter Pauw, owned a severed leg, which was 'not very long', 'covered in thick skin' and furnished with 'broad single scales' according to L'Écluse's detailed description. In addition, the 'accomplished' Christan Porret owned 'certain stones' found in the dodo's stomach. These were 'of different forms, one flat and round[,] the other irregular and angular, an inch in size'. One of these was illustrated next to the dodo [Figure 1]. ${ }^{27}$ L'Écluse included the reader in his experience of when he 'happened to see' Pauw's dodo leg or 'observed' the gastroliths 'at the house of' Porret', associating his own experiences with those of the sailors finding stones in the dodo's stomach in Mauritius. These objects were further associated with the high status of their owners Pauw and Porret. ${ }^{28}$ The detailed and plentiful particulars of each element of L'Écluse's account, arranged elegantly and in a mutually reinforcing way, allowed the reader to be present with him in his work of assembling the animal. This abundance of material created a rich experience of L'Écluse's dodo, and crucially assured the credibility of his description. ${ }^{29}$

Using a set of repeatable images to form a 'type' creature was common in seventeenthcentury natural history, and these assemblages circulated between different texts and images. ${ }^{30}$ L'Écluse's collection of particulars forming the 'Gallinaceus Gallus peregrinus' were far more mobile and easily replicable than physical objects. They were repeated in almost all of the subsequent natural history accounts of the dodo, including the works of Jan Jonston (1657), Juan Eusebio Nieremberg (1635), and Bartolomeo Ambrosini (1642). The dodo became typified by the Mauritian discovery: short legs, scaly feet, peculiar colouring and stomach stones, as L'Écluse described. L'Écluse's description was even favoured over new visual experience by writers of collection catalogues and travelogues: the text could be more potent than the eyes in presentations of knowledge. For example, Nehemiah Grew had seen a whole dodo himself in John Tradescant's cabinet, as well as specimens in the Royal Society's collection, which was far more than L'Écluse ever had. Yet when writing the Royal Society collection catalogue, Grew used L'Écluse's account in his description of the Society's dodo specimens. ${ }^{31}$

\section{A Dutch Dronte in the Historiae naturalis et medicae}

The account of the dodo in the Historiae naturalis et medicae is most unlike that in L'Écluse's work. This volume was published as part of Willem Piso's De Indiae utriusque re naturali et medica... (1658), that included material on both the East and West Indies by several authors. ${ }^{32}$ The tropes describing the dodo may be partly drawn from the Exoticorum. The bird is described as large and fat, with short legs, a large curved beak and 'soft grey plumes' for feathers. It had stones in its stomach and copious but tough breast meat. It appears that 'new' information about the dodo did not accrue over the fifty-three years between these publications. Yet the presentation of these tropes is strikingly different to that in the Exoticorum.

Though there are some mentions of dodos in Batavia and those sent as diplomatic gifts to India and Japan, it is unlikely that de Bondt wrote this account of the dodo. The material is not present in de Bondt's existing manuscripts in the Sherard Collection in Oxford, which formed a basis for the Historiae naturalis. ${ }^{33}$ The dodo account bears none of the emphasis on experiential evidence so apparent in de Bondt's other work and lacks the validating rhetoric evident in L'Écluse's account. ${ }^{34}$ Therefore, this is not a new account of a Mauritian bird from a colonial naturalist, but old material used in a new way. 
The Historiae naturalis et medicae was based on Jacob de Bondt's work on the medicines and nature of the East Indies, assembled and edited after de Bondt's death by Piso. The $1658 \mathrm{De}$ Indiae utriusque re naturali et medica was a compilation of work by several naturalists, including the deceased Georg Marcgraf. Piso admitted that he edited and added to de Bondt's work, but he was very lax about attributions to the other authors. ${ }^{35}$ It is therefore probable that Piso compiled the dodo account integrated into de Bondt's volume, and it is certainly not a story of an original encounter with the dodo. Piso's reasons for including this animal are revealed by a closer look at how he used the images that had been generated and reiterated in other naturalists' works.

Harold Cook has described how de Bondt collected knowledge from local informants, but sent back parcels of transmuted information, commodified and decontextualised 'matters of fact'. ${ }^{36}$ Piso's work appears to be a collection and presentation of just such packages sent from distant parts. The dodo account, however, is a group of images generated in Europe, being used to extend European reach into distant regions of the globe. The volume as a whole works to reinforce the 'Dutch imaginary' of global prowess, encompassing a generalised image of the East and West Indies. It was part of the project of 'omnibus description of the exotic world' prevalent in Dutch publishing of the time, described by the historian Benjamin Schmidt. ${ }^{37}$ The dodo acted as a visual emblem of Piso's product on the frontispiece of his work, amongst a motley crew of other symbolically resonant exotic creatures like the Indian rhinoceros, sloth and parrots [Figure 2]. Piso presented the 'type' dodo, making it into another exotic amongst a panoply of 'wonders' brought back by the VOC enterprise.

In particular, Piso very carefully formed the dodo into a Dutch exotic, the VOC's bird. The first two sentences of the written account demonstrate this clearly:

Among the East Indian Islands is considered that which by others is called Cerne; the name agreed on by our countrymen is Mauritius, chiefly famous on account of its black ebony. In this island a bird of wonderful form named Dronte is numerous. ${ }^{38}$

The island of Mauritius became an East Indian place, drawn into the centre of Dutch trading activity. The Dutch had a settlement on Mauritius for most of the seventeenth century, used first as a landing and re-fuelling site for ships and later as a source of ebony, but by the mid seventeenth century this was of dwindling value. ${ }^{39}$ The Dutch possession of the island was reinforced by the opposition of the previous identity, the island of 'Cerne', given to it by 'others' (the Portuguese), and 'our countrymen' that named it 'Mauritius'. The 'black ebony' for which the island was valued and 'chiefly famous' amongst the Dutch was described even before the dodo. Situated within 'this [very Dutch] island', was the 'wonder' presented to the reader, called the 'Dronte', a 'swollen' bird first consumed by Dutch sailors and 'salted' as provisions for trading ships. ${ }^{40}$ The dodo woodcut accompanying the text, and the dodo on the centre of the frontispiece, seem to have been based on the animals in the paintings of the Dutch artist Roelandt Savery [Figure 3]. Piso was including a 'set piece' animal, made up of images demonstrating the Dutch influence across the Indian Ocean world. He was not seeking out one of the 'eyewitness' images, like the few inaccessible paintings of specimens sequestered in courtly cabinets.

Books such as Piso's were very popular amongst a widening audience of non-scholarly readers interested in this view of the globe arbitrated by Dutch publishers. ${ }^{41}$ Piso's volume used the image of this strange exotic bird to market the global VOC enterprise in both 
Indies. ${ }^{42}$ The dodo may not have had considerable 'extractive capital' as Stephen Greenblatt has termed it, as a physical traded object, but the dodo image was certainly a traded entity with considerable 'mimetic capital'. ${ }^{43}$

\section{Classifying the Dodo}

Assimilating the dodo and other exotics into European natural history in the sixteenth and seventeenth centuries relied upon finding ways to classify them. Classical approaches to understanding the natural world, such as the causal structures developed by Aristotle or descriptive work of Pliny, required development and alteration if new animals and plants were to be incorporated. ${ }^{44}$ We should not assume that early-modern classifications, bearing some resemblance to modern genealogical taxonomies, operated in the same manner. Early-modern schemes were largely based on physical resemblances and emblematic significances. ${ }^{45}$ Perceived geographical provenance was also an important criterion. New creatures were formed by early-modern naturalists in ways that integrated them into these flexible systems of shared symbolic and physical attributes. For example, Peter Mason has desscribed the composition of the 'camel sheep' (South American llama) from the associations with both camels and sheep, and the emendation of Aristotelian categories. Classification corresponded with the place of a specimen in the curiosity cabinet, or in the virtual cabinet of the natural history work. ${ }^{46}$ I will explore several criteria through which the dodo was classified: its geographical localisation, its kinship with other flightless exotic birds and even its 'monstrous' nature.

\section{An 'Indian' bird}

The provenance of the dodo was perhaps the most important characteristic by which it was incorporated into natural history. Geographical symbolism in which animals, plants and peoples were identified with certain geographical regions persisted from the Middle Ages, and proliferated with the exploration of new regions of the world. ${ }^{47}$ It is clearly evident in early-modern maps and frontispieces, as well as the practices of collectors, where stereoyped exotics were used as geographical symbols, reciprocally defining and defined by their distant origins. In particular, the 'Indies' became one of the most significant and complex geographic entities in natural history. The term was used to denote a disparate group of regions in both the East and the West, areas of exotic otherness that were neither static nor always geographically determined. ${ }^{48}$

The dodo was identified in natural histories as both a Mauritian and Indian bird. In his account of the dodo in the Exoticorum, L'Écluse prefaced his description with the detailed particulars of the dodo's discovery by Dutch sailors first landing on Mauritius in $1598 .{ }^{49}$ The discovery of Mauritius and the discovery of the dodo were simultaneous and intertwined facts in L'Écluse's work. The island of Mauritius was characterised by its trusting 'Walghvogel' inhabitants, and the bird defined by the tale of discovery of its island home. ${ }^{50}$ In almost every dodo account after this, the island of Mauritius was an integral part of the description. Subsequently, travel accounts involving the Mascarenes (the islands of Mauritius, Réunion and Rodrigues) published in the seventeenth century invariably included a description of the dodo. For example, the diplomat Thomas Herbert, on a mission to Persia in 1626, described the dodo at length in A relation of some yeares trauaile...Into Afrique and the greater Asia... (1634), despite the fact that he may never have seen the bird. ${ }^{51}$ Whether or not an author had 
seen the animal, the dodo was one of the expected particulars encountered in Mauritius, a standardised image used to represent a passage through the Indian Ocean to readers.

As a result of the routes by which accounts of the dodo and occasionally dodo parts reached Europe, the provenance of the dodo was construed in another way. Through the seventeenth century the dodo was part of the VOC's Indian Ocean trading network, loaded on to ships passing Mauritius en route to the East Indies as provisions for sailors. Perhaps by virtue of its involvement in this circulation of ships and goods in the Indian Ocean, the dodo became an 'Indian bird' in Europe. This is exemplified by Piso's 1658 frontispiece described above, in which the dodo is one of the exotics from a generalised East and West Indies [Figure 2]. ${ }^{52}$

The dodo was similarly characterised in curiosity collections. Collectors and curators often had very limited information about their specimens, their provenance commonly identified from the routes by which they were transported to Europe, if not from textual sources. In a 1609 entry in the catalogue of Rudolf II's Prague Wunderkammer, a specimen of a dodo's beak and head is marked 'A stuffed Indian bird' and associated with L'Écluse's dodo account. ${ }^{53}$ This specimen was placed alongside another 'Indian Bird', the description of which suggests it was the flightless Mauritian red rail, Aphanapteryx bonasia. In later inventories from 1619 and 1621, made after Rudolf's death, several groups of avian specimens probably containing dodo parts were labeled 'Many beaks from Indian Birds'.54

The label of 'Indian' had more symbolic resonance than very specific geographical origins, and was a category often prioritised over those resulting from morphological similarities, at least in the cabinet. Like many other exotic creatures, the dodo's distant origins both perceptually accentuated and causally explained its strange nature. ${ }^{55}$ Perceived, rather than actual, provenance was a definitive aspect of many other new animals during this period. The transshipping of cargoes in West Africa caused the conflation of many creatures from the New and Old Worlds as their original sources became obscured. As a result of this confluence of trade routes and morphological similarities, the New World armadillo and Old World pangolin, and the New World toucans and Old World hornbills, were not initially distinguished. The more familiar example of the 'turkey' also called the kalkoen ('Calicutbird') in Dutch, Gallum Indicum in Latin or poule d'Inde in French (bird of India), all belie the North American origin of the animal and demonstrate the ambiguity of networks of provenance in the identity of exotic creatures. ${ }^{56}$

\section{'Contrary birds'}

Like many other unfamiliar creatures, the seventeenth-century dodo was constructed through the very old technique of metonymic depiction, using a group of more familiar referents. ${ }^{57}$ These descriptions linked the dodo to the domestic swan and chicken, as well as other more familiar exotics such as the ostrich and turkey. It was the 'size of a swan' or 'betwixt an ostrich and a large turkey', and like the 'chicken and rooster'. ${ }^{5}$

Mason describes the effect of this process of description, in which the 'composite creatures partake of the nature of a number of beasts by metonymy, in that a part of the beast, a horn for example, stands for the whole beast'. The assemblage of referents confers not only form but also symbolic function on the chimera. Mason goes on to suggest, however, that 'the resulting figure defies classification... a composite being which is in itself incapable of attribution'. ${ }^{59} \mathrm{I}$ would suggest instead that these composites were indeed distinct, but that their classificatory 
placement resulted directly from these metonymic links. Construction of a chimerical dodo from other flightless birds simultaneously included it within a category of flightless monsters.

The dodo was frequently likened to the ostrich and cassowary or 'emeu', all misshapen birds unable to fly because of their over-large bodies and stunted wings. ${ }^{60}$ Aristotle's On the Parts of Animals provided a precedent for a group of flightless birds, describing birds with 'heavy bodies...not constructed for flight'. ${ }^{61}$ The 'Libyan Ostrich' was rather like a bird in 'being feathered' but rather like a quadruped in being 'unable to soar aloft' and having feathers 'that resemble hair and are useless for flight'. Its other 'discrepancies of structure as compared to the tribe of birds' included hairy eyelashes and 'cloven hoof' ${ }^{62}$ The flightless state was a liminal one, partaking of neither fully avian nor fully terrestrial form, undermining the important avian-mammalian distinction in the same way that Ritvo has described for marsupials and monotremes in the nineteenth century. ${ }^{63}$ This Aristotelian distinction was followed by Ulysse Aldrovandi in his Ornithologiae, placing the ostrich apart from other birds. $^{64}$

These flightless birds were linked by other characteristics too. The stones found in dodo crops became evidence for their ability to swallow burning coals or to digest stone and iron, traits that had been ascribed to the ostrich and recently-arrived cassowary. ${ }^{65}$ In his geography of 1657, Samuel Clarke described how the dodo's stomach was 'so hot, that shee digests stones, or Iron, as doth the Ostrich'. ${ }^{66}$ In the account in Piso's publication, the dodo 'partly differs in shape, and partly agrees' with that of the ostrich and turkey. Stone-swallowing was also described here as 'proof these birds agree with the nature of the ostrich': they shared much more than just external characters. ${ }^{67}$

Flightless birds were classified together by naturalists throughout the seventeenth century as a result of their strange morphology and their shared 'natures'. These birds became creatures that contradicted standard avian morphology. Like the 'Indian birds' arranged together in the cabinet, in the natural history work, the flightless exotics formed a conceptual category. L'Écluse's 'Gallinaceus Gallus peregrinus' was placed between the cassowary and Magellanic penguin. In Piso's 1658 work and Willughby and Ray's Ornithology (1678), the dodo was also located next to the 'Emeu' (cassowary). The dodo was one of the monstrous sigils amongst 'Exotic birds with shapes contrary to other fowles', with 'Rudiments of Wings, useless Wings, such as cannot fly with them', like the 'Pengwin', 'Ostritch', 'Emew' and 'Cassaware' in Robert Holme's 1688 Academy of Armoury. ${ }^{68}$ These 'contrary' birds were not problematic, but valuable and highly saleable oddities.

Though piracy and the extensive re-use of images were common features of early-modern publishing, the use of other flightless birds to represent dodos in publications even long after dodo images were prevalent is suggestive. ${ }^{69}$ For example, in an edition of the travelogue detailing the first Dutch landing on Mauritius, Vierder Thiel Der Orientalischen Indien (1600), produced by the printer-engraver brothers Johann Israel de Bry and Johannes Theodor de Bry, one plate depicting a scene on Mauritius shows an unmistakable cassowary striding between palm trees and two more at the waves' edge [Figure 4]. There is undeniably some exaggeration in the plate, betrayed by the vast upturned tortoise shells in which crowds of sailors sit. Yet this plate was re-printed in a number of other publications in the seventeenth century, such as Alain Manesson-Mallet's Description de l'Univers... (1683). Others used cassowaries or penguins to illustrate images of dodos, as in Gillis Joosten Saeghman's 1663 edition of the 1598 voyage material. ${ }^{70}$ The cassowary and dodo were not only similar in form and the routes by which they reached Europe, they were iconographically interchangeable. 


\section{The demonstrative dodo}

The old descriptive technique of metonymy produced a chimerical dodo that was monstrous. ${ }^{71}$ For many early-modern scholars, monsters were things that demonstrated (from the Latin, monstrare) God's plan and His Nature's inner workings. ${ }^{72}$ Mason describes a typology of early-modern monstrosity which can be used to reveal the structural pattern in the making of a monstrous dodo. The attribution of monstrosity was an active construction, itself a classificatory activity. ${ }^{73}$ Depicting the monstrous body involved systematised descriptive patterns that revealed a set of significant abnormalities. ${ }^{74}$ The 'alterity' of a being was embodied in hybridities, bodily displacements, absences, hypertrophies, re-orientations and duplications, amongst other mutations. ${ }^{75}$ Categoric sensitivities persisted into even the nineteenth century, when 'a small divergence from what seemed ordinary or natural' sufficed to make a morally or scientifically revealing 'monster', even if this deviation resulted from a geographical translocation. ${ }^{76}$

A description from the travel account of the VOC official Johan Nieuhof (1682) demonstrates the way in which these patterns were employed for the dodo:

The eyes are large and black, the neck crooked and very thick: the bill is very long, thick and pale blue... He is very thick and round of body...the belly and hindermost part are so thick as to touch almost the ground, which is the reason he is easily catch'd. On both sides he has certain pens instead of wings... and instead of the tail five curl'd plumes... His legs are short and thick, with four large claws. $^{77}$

In this description, the dodo presented absences, lacking wings and tail, normal feathers and flight. It suffered from hypertrophies, with a vast bill, thick neck and legs and incredible fatness. In de Bondt's volume the dodo was also described as a 'pygmy' amongst the birds it was likened to - effectively a hybrid, stunted ostrich. ${ }^{78}$

Books of monstrosity were popular at this time, aimed at eliciting shock and wonder from their readers. Yet, constructing monstrousness in natural historical descriptions was not, as might appear to a modern audience, simply a label for an ill-fitting creature. Like the category of the 'marvel', the methodical production of the monstrous was a structured way of dealing with novelty and contradiction. ${ }^{79}$ Making a monster actively dissipated the dissonance between a contrary object and the familiar, and gave that object symbolic potency. Thus the thoroughly un-avian dodo became a Plinian monster, the grotesque parts of its body to be understood as demonstrative symbols.

\section{Contrary birds in the Great Chain}

Categorised together and made monstrous, how were dodos and other flightless birds positioned within Creation? The paintings of Northern European artists illustrate the cosmological roles they played well. Analysis of the paradisiacal landscapes of the Flemish painter Jan Brueghel the Elder reveals his use of the landscape as an organising principle within which different faunal elements were classified spatially. ${ }^{80}$ Waterfowl, large heavy birds, small perching birds and those from different regions were grouped together in the appropriate part of the landscape. The effect of such organisation is evident in a painting like Allegory of Air (1611), in which an avian chain of being is demonstrated: the large flightless 
birds like the cassowary, turkey and ostrich, crowded at the bottom corner with storks and pelicans, giving way to increasingly flighty and petite species, culminating in the perpetually aerial birds of paradise near the heavens. ${ }^{81}$ Far from being troubling elements, these unusual exotics were well integrated into early-modern cosmological schemes.

The Dutch painter Roelandt Savery (1576-1639) produced at least ten paintings that included the dodo between 1620 and 1639, many of which were Edenic landscapes demonstrating a similar Chain of Being organisation to Brueghel's Air. In Savery's Das Paradies (1626), for example, the dodo is placed in a lower corner of the image, along with other flightless birds and quadrupeds, in stark contrast to the ethereal birds in the skies. ${ }^{82}$ Far from being an illfitting element, the dodo fills a necessary and earthy role. ${ }^{83}$ Savery used this placement pattern through a series of his paintings, repeating the doleful dodo in the corner. ${ }^{84}$

Another painting by Franz Rosel von Rosenhof, Paradise before the Fall (1690 or 1695, Statens Museum for Kunst) and Earth after the Fall of Man (1690, Statens Museum for Kunst) show even more dramatically the cosmological understanding of the dodo. The bird is absent from the Edenic scene present in the first painting, but appears in the latter, standing amidst a post-Fall chaos of writhing beasts, along with a flustered ostrich, while elephants and other land mammals are carried aloft by eagles. As a liminal creature, violating the avian norms and encroaching on the mammalian, the dodo was very much a postlapsarian creature. $^{85}$

\section{A bird formed for gluttony.}

One of the most striking seventeenth-century paintings of a dodo is 'The DoDo' (c.1627), attributed to Savery and presented to the Natural History Museum in London in 1759. It portrays a large and bulbous creature full-frame, with rolls of grey-feathered flesh around its breast, delicately curled yellow tail plumes set high on its rump, and a thick hooked bill. In contrast to Savery's landscapes, this dodo dwarfs the macaws and ducks that surround it in both size and the visual impact of its bulk [Figure 5]. Savery painted more images of the dodo than any other artist, but it is not certain what experience he actually had of the bird. It is possible that he either worked from a live dodo at some point or with stuffed specimens in Amsterdam and elsewhere. ${ }^{86}$ This bloated and greedy-looking creature epitomises one of the most significant aspects of the dodo imagery in Europe, and is the image of the bird that persists to this day. 'The DoDo' and Savery's other bulbous birds were the gluttons in the dark corners of his paintings, concerned with the bodily and the base.

The textual counterparts to the imagery of Savery's paintings demonstrate one of the strands of moral meaning running through the European imagery of the dodo. I will look at the one of the dodo's emblematic functions here, as an emblem of 'gluttony'. The publications in which the dodo was included certainly did not include explicit emblematic material in the way that earlier texts such as Conrad Gesner's Historia Animalium (1555-8) would have done. Yet, the parts and images from which the dodo was fashioned had implicit emblematic significances. The production of an integrated theological outlook as described by Jorink or Sleigh might have involved the working through of emblematic associations, but symbolic perceptions of creatures were still very prevalent well into the eighteenth century. ${ }^{87}$

The first travelogues describing sailors' experiences of catching and eating the bird as well as subsequent travel accounts focus on its form and flesh. ${ }^{88}$ The dodo was freely available in Mauritius, being too stupid and fat to escape hunters, and so a 'great multitude' were 
caught. ${ }^{89}$ This bounty was excessively plentiful, as one bird was said to sate the appetite of 25 men. Thus the remains were discarded carelessly overboard. ${ }^{90}$ It was called Walghvogel in Dutch and oiseaux de nausée in French, based on the idea that the bird sickened sailors with its 'greasie' meat or cloying taste. ${ }^{91}$ Dodo meat was difficult to digest, tough, simultaneously over-nourishing and unsavoury. It was 'offensive and of no nourishment' to 'delicate' palates, only good for 'greasie stomackes'. ${ }^{92}$ One report asserted that the meat could never be cooked satisfactorily. ${ }^{93}$

In later natural histories and travelogues, the dodo's gluttonous nature is further exaggerated in its form and behaviour. It was 'rotund' and 'extream fat', so large that its bottom dragged on the ground as it walked on its thick, short legs. ${ }^{94}$ Its appetite was 'strong and greedy', according to Herbert. In the description in de Bondt's Historiae naturalis, the 'gape' of the dodo's 'sharp, pointed and hooked' beak was described as 'hideous, greatly broad, as if formed for gluttony'. ${ }^{95}$ This symbolic role as a gluttonous bird that the dodo acquired gave rise to accounts of its ability to devour anything, even the most unpalatable substrates described above. ${ }^{96}$ These accounts became more extreme through the seventeenth century as the iconography of the greedy bird developed.

The moral implications of this all-consuming nature are suggested by the uses of flightless birds in emblems into the eighteenth century. One Dutch emblem from Jan Luiken's De Bykorf Des Gemoeds (1711) pictures a startled-looking ostrich at which onlookers gesture. It is entitled 'Onverstandig!' ('Unwise!'), and is accompanied by a quotation from the book of Matthew, 16:2: 'For what is a man profited, if he shall gain the whole world, and lose his own soul?'. ${ }^{97}$ The greed attributed to the dodo was drawn from the all-consuming appetite of the ostrich originally suggested by Pliny. ${ }^{98}$ They shared the earth-bound nature and corresponding soulless state resulting from the morally abject sin of gluttony. The Dutch mercantile classes were keenly aware of the moral dangers of their own success. ${ }^{99}$ The VOC was a vastly profitable but also an all-consuming organisation, which brought back such copious quantities of goods from all over the globe. ${ }^{100}$ Moral repugnance resulting from this surfeit contributed to the development of assiduously modest behaviours of consumption in the Netherlands. ${ }^{101}$ The force of military power coupled with market monopolies proved advantageous for the Netherlands, but devastating to many areas of the world, and eventually unsustainable for the VOC itself. ${ }^{102}$ The dodo, ironically, came to embody the questionable moral status of the aggressive VOC trading enterprises, functioning as an emblem of human gluttony in the very volumes that marketed the VOC's spoils to the European audience. ${ }^{103}$

\section{Conclusion}

In a broad sense, the dodo of Mauritius never arrived in Europe. It was never really encountered by European naturalists, and was certainly not problematic for them. The dodo of European natural histories was assembled from a scant collection of dismantled parts and travel accounts by seventeenth-century naturalists such as L'Écluse. It was a chimerical amalgamation of tropes that were easily replicable and saleable, integrated into European classifications and cosmology by virtue of this assembly process. The existing European classificatory structures were highly malleable: striking geographical, symbolic or morphological distinctions could be used to form new groupings, while the Great Chain of being was infinitely divisible. ${ }^{104}$ The production of monstrosity itself was a classificatory process, which registered contradictions in painstaking detail whilst simultaneously dissipating them. The dodo's constituent tropes were also potent symbols. To describe the 
dodo was to describe the first Dutch landing in Mauritius, or to describe the tangible feet and stones in collections - and vice versa. In just the same way to describe the dodo was to invoke the ostrich, cassowary or turkey.

These concrete associations carried moral implications inherent in the persistently emblematic outlook of seventeenth-century natural history. The dodo was seen as a glutton because of its rotund form, but this engorged body resulted from the making of it as a glutton, and not the other way around. In hindsight, the projection of profitable yet bloating consumption onto the form of this bird concluded with unhappy simultaneity for both the VOC and the dodo. The dodo was a moral victim of its own too-rich flesh, its resulting fate a dwindling population and eventual extinction in the 1680's to 1690's. During this same period, the VOC began to suffer from the costs of maintaining its far-reaching enterprises, gradually losing its hold over the Indian Ocean world as its profitability and viability declined. ${ }^{105}$ The dodo has certainly not lost its emblematic role as a symbol of greed. It's modern day significance, however, rests not the gluttony of the bird itself, rather, on it being a well-known victim of the potentially devastating environmental effects of human activities.

* Department of History and Philosophy of Science, University of Cambridge, Free School Lane, Cambridge CB2 3RH, UK. Email: nl272@,cam.ac.uk.

This article is the result of research carried out for my $\mathrm{PhD}$ thesis, funded by the AHRC. Many thanks to Professor Simon Schaffer and Professor Nick Jardine for their invaluable support in the writing of this article, as well as to Charlotte Sleigh and the anonymous reviewers who made many insightful and helpful comments.

${ }^{1}$ For example, Anthony Cheke and Julian Hume, Lost Land of the Dodo: An Ecological History of Mauritius, Reunion and Rodrigues, London: Poyser, 2008; Jolyon C. Parish, The Dodo and the Solitaire, A Natural History, Indiana University Press, 2013, p. 108. I am indebted to this volume for the translations of many of the Dutch and Latin primary texts.

${ }^{2}$ Emma C. Spary, 'Of Nutmegs and Botanists: the colonial cultivation of botanical identity', in Londa Schiebinger and Claudia Swan (eds.), Colonial Botany: Science, Commerce, and Politics in the Early Modern World, Philadelphia: University of Pennsylvania Press, 2005, pp. 8, 203.

${ }^{3}$ Brian W. Ogilvie, The Science of Describing: Natural History in Renaissance Europe, University of Chicago Press, 2006, p. 209; Harriet Ritvo, The Platypus and the Mermaid, Harvard University Press, 1997.

${ }^{4}$ Anthony Grafton, New Worlds, Ancient Texts: The Power of Tradition and the Shock of Discovery, Harvard University Press, 1995, p. 1, epilogue; Florike Egmond, The World of Carolus Clusius: Natural History in the Making, 1550-1610, London: Pickering \& Chatto 2010 pp. 206.

${ }^{5}$ Florike Egmond, 'Names of Naturalia in the Early Modern Period: between the Vernacular and Latin, Identification and Classification', in Translating Knowledge in the Early Modern Low Countries, ed. Harold J. Cook and Sven Dupré (London and Berlin, 2013), pp. 144-149; Londa Schiebinger, Plants and Empire: Colonial Bioprospecting in the Atlantic World, Harvard University Press, 2004, p. 62; Dániel Margócsy, Commercial Visions: Science, Trade and Visual Culture in the Dutch Golden Age, London: University of Chicago Press, 2014, p. 65 . 
${ }^{6}$ Paula Findlen, 'Natural History', in Katharine Park and Lorraine Daston (eds.), Early Modern Science, Cambridge: Cambridge University Press, 2006, p. 449.

${ }^{7}$ See Peter Mason, Before Disenchantment: Images of Exotic Animals and Plants in the Early Modern World, Reaktion Books, 2009.

${ }^{8}$ Grafton, for example, comments on the 'astonishing flexibility and resilience' of authoritative texts as tools for understanding novel things (Grafton op. cit. (4), p. 10)

${ }^{9}$ William Ashworth Jr., 'Emblematic Natural History of the Renaissance', in Nick Jardine, Anne Secord \& Emma Spary, Cultures of Natural History, Cambridge University Press, 1996, pp. 17-37.

${ }^{10}$ William Ashworth Jr., 'Natural History and the Emblematic World View', in David C. Lindberg, Robert S. Westman (eds.), Reappraisals of the Scientific Revolution, Cambridge Univeristy Press, 1990, pp. 317-319.

${ }^{11}$ Charlotte Sleigh, 'Jan Swammerdam's Frogs', Notes Records of the Royal Society (2012) 66:4, pp. 373-392.

${ }^{12}$ Eric Jorink, 'Between Emblematics and the 'Argument from Design': The Representation of Insects in the Dutch Republic', in Karl A.E. Enenkel and Paul J. Smith (eds.), Early Modern Zoology: The Construction of Animals in Science, Literature and the Visual Arts, Leiden and Boston: Brill, 2007, pp. 147-176.

${ }^{13}$ Karin Leonhard, 'Shell collecting. On $17^{\text {th }}$-century conchology, curiosity cabinets and still life painting', in in Karl A.E. Enenkel and Paul J. Smith (eds.), Early Modern Zoology: The Construction of Animals in Science, Literature and the Visual Arts, Leiden and Boston: Brill, 2007, p. 186.

${ }^{14}$ After the VOC base at the Cape was established in 1652, trading ships en route to the Indies rarely stopped at Mauritius. Ships frequently remained in the Indies for some time, so that trading trips could take several years to return to Europe (Cheke and Hume, op. cit. (1) p. 75); Dániel Margócsy, op. cit. (5), p. 25.

${ }^{15}$ See Parish, op. cit. (1), ch. 5.

${ }^{16}$ Findlen, op. cit. (6), p. 449.

${ }^{17}$ Mason, op. cit. (7), pp. 127-130; See Egmond, op. cit. (4), especially chapters 9 and 12, for a detailed discussion of the networks within which exotics were circulated and studied.

${ }^{18}$ Mason, op. cit. (7), p. 128; There could also be close relationships and considerable collaboration in sourcing objects and information within natural history networks, as Egmond demonstrates, (Egmond, op. cit. (4), pp. 191-207).

${ }^{19}$ Mason, op. cit. (7), p. 130.

${ }^{20}$ See Michael Wintroub, 'The Looking Glass of Facts: Collecting, Rhetoric and Citing the Self in the Experimental Natural philosophy of Robert Boyle', History of Science (1997) xxxv (pp. 189-217), p. 189.

${ }^{21}$ Findlen has described how engagement with material culture became central to philosophical enquiry (Paula Findlen, Possessing Nature: Museums, Collecting, and Scientific Culture in Early Modern Italy, University of California Press, 1996, introduction).

MacGregor describes how the library and cabinet were closely linked, and 'often interpenetrated one another' (Arthur MacGregor, Curiosity and Enlightenment: Collectors and Collections from the Sixteenth to the Nineteenth Century, Yale University Press, 2007, p. $32)$.

${ }^{22}$ Steven Shapin, 'Pump and Circumstance: Robert Boyle's Literary Technology', Social Studies of Science (1984) 14:4, pp. 481-520; Wintroub, op. cit. (6), p. 207.

${ }^{23}$ Admiral Jacob Cornelisz Van Neck, Het Tweede Boeck (1601, 2nd edition of a lost Dutch 1600 edition) fol. 7v, quoted in Parish, op. cit. (1), pp. 8-9. 
${ }^{24}$ Parish, op. cit. (1), p. 108; Harold Cook has described how L'Écluse and his colleague Peter Pauw endeavoured to make arrangements with travellers to gain access to information from voyages, in Matters of Exchange: Commerce, Medicine and Science in the Dutch Golden Age, Connecticut: Yale University Press, 2007, p. 129; Egmond demonstrates how L'Écluse's contacts endeavoured to source direct information for him on exotics (Egmond, op. cit. (4), pp. 191-207).

${ }^{25}$ Parish, op. cit. (1), p.107; Charles L'Écluse, Exoticorum libri decem: quibus animalium, plantarum, aromaticum, aliorumque, peregrinorum fructum historiae describuntur, Leiden, 1605, p. 100.

${ }^{26}$ Daniel Carey, 'Compiling nature's history: Travellers and travel narratives in the early Royal Society', Annals of Science, (1997) 54:3, (pp. 269-292), pp. 270-71; Anthony Pagden, European Encounters with the New World, Yale University Press, 1993, p. 51.

${ }^{27}$ These stones are today termed gastroliths, swallowed to aid digestion of roughage (Parish, op. cit. (1), pp. 107-108); L'Écluse, op. cit. (25), pp.100-101.

${ }^{28}$ See Stephen Bann, Under the Sign: John Bargrave as Collector, Traveller, and Witness, University of Michigan Press, 1994; Susan M. Pearce, On Collecting: an investigation into collecting in the European Tradition, Routledge, 1995, p. 181. The social fashioning of experiential knowledge claims was described in Shapin, op. cit. (22).

${ }^{29}$ Wintroub describes textual methods in developing the credibility of testimony, including 'performative acts of self-citation' and 'correct display of copia' (Wintroub, op. cit. (20), p. 200).

${ }^{30}$ For example, see Paul Smith, 'On Toucans and Hornbills: Readings in Early modern Ornithology from Belon to Buffon', in Karl A.E. Enenkel and Paul J. Smith (eds.), Early Modern Zoology: The Construction of Animals in Science, Literature and the Visual Arts, Leiden and Boston: Brill, 2007; Benjamin Schmidt, 'Collecting Global Icons: The Case of the Exotic Parasol'. In Collecting Across Cultures: Material Exchanges in the Early Modern Atlantic World, edited by Daniela Bleichmar and Peter Mancall. University of Pennsylvania Press, 2011.

${ }^{31}$ Nehemiah Grew, Musaeum Regalis Societatis: Or a Catalogue and Description of the Natural and Artificial Rarities Belonging to the Royal Society..., London: Rawlins, 1681, pp. 153-4.

${ }^{32}$ Piso's De Indiae utriusque re naturali et medica... (1658) was an extended version of the earlier Historia Naturalis Brasiliae (1648). For a detailed history of the publication of this volume, see Cook, op. cit. (24), pp. 218-224.

${ }^{33}$ See Parish, op. cit. (1), ch.5; Ria Winters and Julian P. Hume, 'The dodo, the deer and a 1647 voyage to Japan', Historical Biology: An International Journal of Paleobiology (2014) 27: 2, pp. 258-264; MS Sherard 186, (1630), Sherard Collection, Plant Sciences Library, Oxford.

${ }^{34}$ Harold J. Cook, 'Global Economies and Local Knowledge in the East Indies: Jacobus Bontius learns the facts of nature', in Londa Schiebinger and Claudia Swan (eds.), Colonial Botany: Science, Commerce, and Politics in the Early Modern World, Philadelphia: University of Pennsylvania Press, 2005, p. 112.

${ }^{35}$ The Historiae naturalis was produced posthumously from de Bondt's unpublished manuscript material on East Indian animals as well as his previsouly published work on medicines, De Medicina Indorum (1642). Sometimes Piso's alterations led to his inaccuracies and conflations being unfairly blamed on the deceased contributors (Cook, op. cit. (24), pp. 218-221).

${ }^{36}$ Cook, op. cit. (34), pp. 117-118. 
${ }^{37}$ Benjamin Schmidt, 'Accumulating the world: collecting and commodifying 'globalism' in early modern Europe', in Lissa Roberts (ed.), Cycles and Centres of Accumulation in and Around the Netherlands During the Early Modern Period, Berlin and Zurich: LIT, 2011, pp. 130-134; Julie Berger Hochstrasser, 'The conquest of spice and the Dutch colonial imaginary: seen and unseen in the visual culture of trade', in Londa Schiebinger and Claudia Swan (eds.), Colonial Botany: Science, Commerce, and Politics in the Early Modern World, Philadelphia: University of Pennsylvania Press, 2005, pp. 176-177.

${ }^{38} \mathrm{Jacob}$ de Bondt, Historiae naturalis et medicae Indiae Orientalis libri sex, Amsterdam: Elzevir, 1658, pp. 70-71.

${ }^{39}$ Cheke and Hume op. cit. (1), p. 76; Alette Fleischer, 'The Company's garden and the (Ex)change of Nature and Knowledge at Cape of Good Hope (1652-1700)', in Lissa Roberts (ed.), Cycles and Centres of Accumulation in and Around the Netherlands During the Early Modern Period, Berlin and Zurich: LIT, 2011, p. 101.

${ }^{40}$ de Bondt quoted in Parish, op. cit. (1), pp. 114-115. Dronten means 'swollen' in Dutch, and is probably the source of this name, along with the other Dutch appellation 'Dodoaers' (Parish, op. cit. (1), p.135).

${ }^{41}$ Schmidt, op. cit. (37), p.130; Hochstrasser, op. cit. (37), p. 171; Benjamin Schmidt 'Inventing exoticism' in Paula Findlen and Pamela Smith (eds.), Merchants and Marvels: Commerce, Science and Art in Early Modern Europe, New York: Routledge, 2001, p. 350. ${ }^{42}$ Cook, op. cit. (34), p. 101.

${ }^{43}$ Stephen Greenblatt, Marvelous Possessions: The Wonder of the New World, Oxford University Press, 2003, pp.6-7: Greenblatt describes mimetic capital as a 'stock of images, along with the means of producing those images' circulating according to 'prevailing market forces'; Schmidt, op. cit. (41), p. 362; Egmond cautions against characteristing the varied relationships between naturalia, social interaction and commerce too narrowly, however, (Egmond, op. cit. (4), p.155).

${ }^{44}$ Findlen, op. cit. (6), pp. 464, 439.

${ }^{45}$ Karin Leonhard, 'Shell collecting. On $17^{\text {th }}$-century conchology, curiosity cabinets and still life painting', in in Karl A.E. Enenkel and Paul J. Smith (eds.), Early Modern Zoology: The Construction of Animals in Science, Literature and the Visual Arts, Leiden and Boston: Brill, 2007, pp.177-214; Egmond, op. cit. (5), pp. 144-149.

${ }^{46}$ For example, Schmidt, op. cit. (30) pp. 31-57; Peter Mason, 'From presentation to representation: Americana in Europe'. Journal of the History of Collections, 6:1 (1994), pp.120. Collections were used to 'draw a map of knowledge'. Collection catalogues, which developed significantly from plain texts to encompassing the 'imaginative possibilities' of the collection, extended this structure of knowing. (Findlen, op. cit. (21), pp. 32-47).

${ }^{47}$ Petrus Plancius's Orbis terrarum..., (1594) is a good example of this geographical imagery. For an example of 'collecting the world' in the colonial context, see Rebecca P. Brienen, 'From Brazil to Europe: The Zoological Drawings of Albert Eckhout and Georg Marcgraf', in Karl A.E. Enenkel and Paul J. Smith (eds.), Early Modern Zoology: The Construction of Animals in Science, Literature and the Visual Arts, Leiden and Boston: Brill, 2007, pp. 27982; also Anthony Alan Shelton, 'Cabinets of Transgressions: Renaissance Collections and the Incorporation of the New World', in John Elsner and Roger Cardinal, The Cultures of Collecting (critical views), 2004, Reaktion Books.

${ }^{48}$ Findlen, op. cit. (6), p. 450.

${ }^{49}$ This may have been gathered from the early published accounts like the Waraachtige Beschryving (Anonymous, 1599) or other unpublished accounts (Parish, op. cit. (1), p.108). ${ }^{50}$ L'Écluse, op. cit. (25), pp.99-101. 
${ }^{51}$ Thomas Herbert, A relation of some yeares trauaile begunne anno 1626. Into Afrique and the greater Asia... London, 1634, pp. 211-212.

${ }^{52}$ Willem Piso, De Indiae utriusque re naturali et medica, libri quatuordecim, Amsterdam: Elzeviros, 1658, Frontispiece.

${ }^{53}$ Daniel Fröschl, p. 114 of 1609 entry of 1607-11 inventory, cited in Parish, op. cit. (1), pp. 179-180.

${ }^{54}$ Parish, op. cit. (1), pp. 178-179; The collector Bernardus Paludanus also referred to 'strange large beaks of Indian birds', amongst which there may have been a dodo (Parish, op. cit. (1), pp. 192, 378). Eventually, the beak of the Prague dodo was all that was left of the original stuffed specimen, and was discovered in the nineteenth century (Parish, op. cit. (1), pp. 180186).

${ }^{55}$ Scholars hypothesised about the effects of the extreme conditions in other regions of the globe on living things (Jorge Cañizares-Esguerra, Nature, Empire \& Nation: Explorations of the history of Science in the Iberian World, Stanford University Press, 2006, pp.73-75).

${ }^{56}$ Natalie Lawrence, 'Exotic origins: The emblematic biogeographies of early modern scaly mammals', Itinerario, forthcoming; Smith, op. cit. (30), p. 77: note that Smith links kalkoen to the town of Calcutta, but this is possibly mistaken; de Bondt, op. cit. (38), p. 70.

${ }^{57}$ Ogilvie, op. cit. (3); Mason, op. cit. (7), p. 112.

${ }^{58}$ Pliny the Younger, Des wijdt-vermaerden Natur-kondigers vijf Boecken (c.1650, book 3 ) cited in Parish, op. cit. (1); Johan Nieuhof, Voyages and Travels to the East Indies 1653-1670 (Oxford in Asia Historical Reprints), Singapore: Oxford University Press, 1988; L'Écluse op. cit. (25), pp. 100-101.

${ }^{59}$ Mason, op. cit. (7), p. 113.

${ }^{60}$ Herbert, op. cit. (51), pp. 211-212.

${ }^{61}$ Grafton, op. cit (4), ch. 4.

${ }^{62}$ Aristotle, De Partibus Animalium, book IV, ch. 12, 14.

${ }^{63}$ Ritvo, op. cit. (3), pp.10-13

${ }^{64}$ Arianne Faber Kolb, Jan Brueghel the Elder, the Entry of the Animals into Noah's Ark, Los Angeles: Getty Publications, 2005, p. 31.

${ }^{65}$ Francis Willughby and John Ray, The Ornithology of Francis Willughby, London, 1678, p. 152.

${ }^{66}$ Samuel Clarke, A Geographical Description of All the Countries in the Known World, London: Tho Molbourn, 1671, p. 217.

${ }^{67}$ de Bondt, op. cit. (38), pp. 70-71; Parish, op. cit. (1), pp. 114-115.

${ }^{68}$ Randle Holme, The Academy of Armory, or, A storehouse of armory and blazon containing the several variety of created beings..., London, 1688, pp. 308-309.

${ }^{69}$ Adrian Johns, Nature of the Book: Print and Knowledge in the Making, University of Chicago Press, 2000, pp. 138, 183.

${ }^{70}$ Parish, op. cit. (1), p. 7.

${ }^{71}$ Mason, op. cit. (7), p. 112.

72 Dudley Wilson, Signs and Portents: monstrous births from the Middle Ages to the Enlightenment, London: Routledge, 1993, p. 6.

${ }^{73}$ Mason, op. cit. (7), p. 103.

${ }^{74}$ Bacon argued that monsters were valuable 'deviating instances' with which to investigate nature, (Wilson, op. cit. (72), p. 73).

${ }^{75}$ See Mason, op. cit. (7), ch. 3.

${ }^{76}$ Ritvo, op. cit. (3), p.131-44

${ }^{77}$ Nieuhof, op. cit. (58), p. 313.

${ }^{78}$ Mason, op. cit. (7), ch. 3; de Bondt op. cit. (38), pp. 70-71; Parish, op. cit. (1), pp. 114-115. 
${ }^{79}$ Greenblatt, op. cit. (43), pp. 73-81.

${ }^{80}$ Faber Kolb, op. cit. (64), pp. 26-31.

${ }^{81}$ The connections between natural history and art were manifold in this period, as demonstrated for the birds of paradise in José Ramón Marcaida, 'Rubens and the bird of paradise. Painting natural knowledge in the early seventeenth century', Renaissance Studies (2014) 28:1, pp. 112-127. Several historians have described how artists included an encyclopedic array of novel exotica in their paintings, where they played both symbolic and allegorical functions. For example, see Leonhard, op. cit. (45), pp. 177-214.

${ }^{82}$ Currently at the Gemäldegalerie Alte Meister der Staatliche Museen zu Berlin (Parish, op. cit. (1), p. 79).

${ }^{83}$ Arthur Oncken Lovejoy, The Great Chain of Being: A Study of the History of an Idea, Harvard University Press, 1936: He describes the two principles of plenitude and continuity in the conceptual framework of the Chain of Being, the latter of which is demonstrated in the role of the dodo described here.

${ }^{84}$ See Parish, op. cit. (1), ch. 3 for a full account of these images.

${ }^{85}$ My thanks to Dániel Margócsy for bringing these paintings to my attention.

${ }^{86}$ Possible models for Savery's paintings are the stuffed specimen in Amsterdam, Rudolf II's specimen at Prague, Maurits of Nassau's menagerie bird, as well as a number of other birds speculated to have been imported. Parish suggests that the Amsterdam bird was probably the model (Parish, op. cit. (1), pp. 76-77).

87 Jorink, op. cit. (12), pp.147-176; Sleigh, op. cit. (11). This persistence is demonstrated by the enduring popularity of emblem books through this period (John Manning, The Emblem, Reaktion books, 2002, p. 14; Mario Praz, Studies in Seventeenth-century Imagery, 2nd edn. Rome: Storia e Letteratura, 2001, pp. 15, 199, 201), as well as work on the use of the 'Poison' Upas tree as a malleable symbol of colonial interactions (Michael Dove and Carol Carpenter. 'The "Poison Tree" and the Changing Vision of the Indo-Malay Realm', in Reed L. Wadley (ed.), Histories of the Borneo Environment: Economic, Political and Social Dimensions of Change and Continuity, Netherlands: KITLV Press, 2005, pp. 183-212.)

${ }^{88}$ Jan Den Hengst reviews edibility accounts thoroughly in his article, 'The dodo and scientific fantasies: durable myths of a tough bird', Archives of Natural History (2009), 36:1, pp. 136-145.

${ }^{89}$ Neck, op. cit. (23).

${ }^{90}$ Admiral Cornelis Matelief, Historische Verhael Vande treffelijcke Reyse...(1646), ch. 15, fol. 22v, quoted in Parish, op. cit. (1), p. 27; Van der Hagen, quoted in Parish, op. cit. (1), p. 28.

91 Anon, Waarachtig Beschryving (1599), quoted in Parish, op. cit. (1), pp. 8-10; Herbert, op. cit. (51), pp. 211-212; Nieuhof, op. cit. (58), p. 312.

92 Parish op. cit. (1), pp. 114-5; Anon, quoted in Parish op. cit. (1), pp. 8-10; Herbert, op. cit. (51), p. 212.

${ }^{93}$ West-Zanen (1648, Amsterdam: H. Soete-boom), quoted in Parish, op. cit. (1), pp. 24-25.

${ }^{94}$ De Bondt, op. cit. (38), p.70; Clarke, op. cit. (66), p. 217; Bontekoe quoted in Parish op. cit. (1), pp. 122-123; Nieuhof, op. cit. (58), p. 312.

${ }^{95}$ Herbert, op. cit. (51), p.211-2; De Bondt, op. cit. (38), pp. 70-71; De Bondt in Parish, op. cit. (1), pp. 114-115.

${ }^{96}$ Willughby and Ray, op. cit. (65), p. 152; De Bondt, op. cit. (38), p. 71; Nieuhof, op. cit. (58), p. 312; Clarke, op. cit. (66), p. 217

${ }^{97}$ Jan Luiken, De Bykorf Des Gemoeds, Honing zaamelende uit allerly Bloemen: Vervattende over de Honderd konstige Figuuren..., Amsterdam, 1711, p. 106.

${ }^{98}$ Pliny, Natural History, X, 1, p. 292-293 
${ }^{99}$ See Simon Schama, The Embarrassment of Riches: An Interpretation of Dutch Culture in the Golden Age, (reissue), Harper Perennial, 2004.

${ }^{100}$ Johan de Jhong, 'Drawing Ships and Spices', in Lissa Roberts (ed.), Cycles and Centres of Accumulation in and Around the Netherlands During the Early Modern Period, Berlin and Zurich: LIT, 2011, p. 177.

${ }^{101}$ Schama, op. cit. (99).

${ }^{102}$ Hochstrasser, op. cit. (37), pp. 171-176.

${ }^{103}$ Schmidt, op. cit. (37), pp. 129-131.

${ }^{104}$ Lovejoy, op. cit. (83)

${ }^{105}$ D. L. Roberts and A. R. Solow, 'Dutch diaries and the demise of the dodo', Nature (2003) 426, pp. 426, 245: the exact date is unknown, but the dodo's extinction was precipitated by anthropogenic habitat destruction, over-hunting and the ravages of introduced ground mammals. This unprofitability was obscured for a long time as a result of the complex accounting system that was used (Hochstrasser, op. cit. (37), p. 181). 